\title{
Land Change in Eastern Mediterranean Wood-Pasture Landscapes: The Case of Deciduous Oak Woodlands in Lesvos (Greece) ${ }^{1}$
}

Harald Schaich ${ }^{1,2}$, Thanasis Kizos, ${ }^{3}$ Stefan Schneider ${ }^{2,4}$, Tobias Plieninger ${ }^{5}$

1 Department of Environmental Planning, Landscape Ecology and Nature Conservation, Environmental Protection Agency, City of Freiburg, Talstr. 4, 79102 Freiburg, Germany

2 Chair for Landscape Management, Institute of Earth and Environmental Sciences, Faculty of Environment and Natural Resources, University of Freiburg, Tennenbacher Str. 4, 79106 Freiburg, Germany

3 Department of Geography, University of the Aegean, University Hill, 81100 Mytilene, Greece

4 Chair for Silviculture, Institute of Forest Sciences, Faculty of Environment and Natural Resources, University of Freiburg, Tennenbacher Str. 4, 79106 Freiburg, Germany

5 Department of Geosciences and Natural Resource Management, University of Copenhagen, Rolighedsvej 23, 1958 Frederiksberg C, Denmark

\section{Corresponding author:}

Harald Schaich, harald.schaich@stadt.freiburg.de

\footnotetext{
${ }^{1}$ This text is a preprint. Please cite as: Schaich H., T. Kizos, S. Schneider, T. Plieninger (2015): Land change in Eastern Mediterranean wood-pasture landscapes: The case of deciduous oak woodlands in Lesvos (Greece). Environmental Management 56(1): 110-126. The original publication is available at: http://dx.doi.org/10.1007/s00267-015-0496-y.
} 


\begin{abstract}
In Mediterranean Europe, wood-pasture landscapes with oak woodlands as emblematic ecosystems are undergoing rapid land-use change, which may threaten their legacy as hotspots of biodiversity, ecosystem services, and cultural heritage. The objective of this study was to quantify land cover changes and transitions as well as the dynamics of oak woodland patterns and densities over 50 years in two municipalities at the center and edges of Quercus macrolepis distribution in Northern Lesvos (Greece). We used aerial photographs from 1960 and WorldView-2 satellite images from 2010 to process land cover maps and metrics, and to calculate oak canopy cover with a point-grid sampling approach. Spatiotemporal dynamics of land cover change were generally high - especially between oak woodlands and grass- and shrub-lands, resulting in a more heterogeneous and fragmented land- scape in 2010. Surprisingly, oak woodland area remained stable with marginal losses in one study site and gains in the other one. Oak canopy cover increased by 8 and $9 \%$. Spatial hotspots of change were mountainous and peripheral phrygana areas with expanding oak stands, as well as river valleys and near urban areas with expanding olive groves and grass- and shrublands in former complex cultivation and oak stands. We conclude that the parallel processes of abandonment of crop cultivation and intensification of livestock grazing have been less detrimental to oak woodlands than supposed. To ensure long-term persistence of oak woodlands in the face of ongoing rural depopulation and land-use intensification, environmental and agricultural policies should better address their specificities as anthropogenic habitats.
\end{abstract}

\title{
Keywords
}

Agroforestry, Biodiversity conservation, Cultural landscapes, Fragmentation, Landscape metrics, Land-use change 


\section{Introduction}

Silvopastoral oak woodlands are emblematic ecosystems in Mediterranean Europe, often defining whole wood-pasture landscapes (Grove and Rackham 2001). There are around 3.3 million ha of holm oak (Quercus rotundifolia), cork oak (Q. suber), and Pyrenean oak (Q. pyrenaica) wood- lands in Spain and Portugal, 1.7-2.0 million ha of deciduous oak woodlands (dominated by Q. macrolepis and Q. pubescens with other scattered trees) in Greece and 180,000 ha of woodlands of various oak species in Central and Southern Italy (Garbarino and Bergmeier 2014). Mediterranean oak woodlands are habitats with relatively low tree densities at the interface between open grass- and shrublands and largely closed forests (Costa et al. 2009; Plieninger et al. 2011). They support outstanding levels of biodiversity and ecosystem services and are therefore considered archetypes of high-nature value farmlands in Europe (Oppermann et al. 2012). Many oak woodlands and their respective wood-pasture landscapes have been truly multifunctional given that they supported multiple land- uses with livestock herding, crop cultivation, and wood and/or tree crop production organized in complex spatiotemporal systems (Schaich et al. 2004).

Most oak woodlands and the respective traditional land- use systems in Mediterranean Europe have experienced a rapid collapse since the 1960s, mainly due to dramatic changes in rural economies. A key change has been the demise of the traditional multifunctional land-use systems including the abandonment of crop cultivation, especially in hilly and terraced areas, and of forestry practices and tree crop uses (Kizos et al. 2013). Another important aspect of change in many wood-pasture landscapes has been a strong increase in livestock grazing intensities, often accompanied by changes in livestock species (for example, from sheep to cattle), which was favored by the Common Agricultural Policy in the European Union with livestock head payments. These changes have often led to opposing land-use trends, which appeared simultaneously, but spatially separated in the same region: intensified grazing pressure on the one side, but also land abandonment followed by shrub encroachment on the other side. Additional major threats to Mediterranean oak woodlands are decline of old trees, lack of tree regeneration, forest regrowth, and tree diseases (Bergmeier et al. 2010). Legal conservation instruments like the European Union's Habitats Directive (some natural xerothermophilous oak forest types were put under formal protection) and several national conservation efforts since the 1990s could not impede the general land- use change in oak woodlands.

The spatiotemporal dynamics of oak woodlands have been extensively studied in the Western part of the Mediterranean (c.f. Campos et al. 2013). A recent review identified 14 studies that together covered more than $10 \%$ of the total grazed oak woodland area in Spain and Portugal (Costa et al. 2014a). This review identified a general trend towards decreasing area, with an overall average rate of loss of $0.33 \%$ in initial area per year. In contrast, the trajectories of wood-pasture landscapes in the Eastern Mediterranean have received much less attention. Here, oak woodlands are often small-scale and diverse systems, composed of many different oak and other tree species such as Q. pubescens, Q. coccifera, Q. macrolepis, Cas- tanea sativa, and Pinus nigra. Many of the Eastern Mediterranean wood-pasture landscapes combine environmental marginality with unfavorable socio-economic conditions, generating complex social-ecological problems. Extreme changes in the intensity of land-use (for example, grazing levels on pasture lands are now up to eight times above the estimated carrying capacities) have led to severe land degradation and desertification in the Eastern 
Mediterranean (Iosifides and Politidis 2005). Different aspects of the environmental impacts of such degradation processes have been investigated including soil quality and erosion (Arhonditsis et al. 2000; Tsadila et al. 2012; Ari- anoutsou-Faraggitaki 1985), wildfire risks (Kalabokidis et al. 2008), and vegetation (Kosmas et al. 2000a, b). Moreover, it is well established that land degradation triggers feedbacks towards unsustainable production practices, which further exacerbates land degradation (Bakker et al. 2005; Iosifides and Politidis 2005).

Much less is known about how land degradation is related to the dynamics of oak woodlands in the Eastern Mediterranean as well as the landscapes that they are embedded in. Some studies have assessed regeneration, woody species diversity, and stand structure of oak woodlands (e.g., Plieninger et al. 2011) or land cover changes in a broader sense (e.g., Tzanopoulos and Vogiatzakis 2011; Kizos and Koulouri 2006; Dikou et al. 2011). However, the spatiotemporal dynamics of Eastern Mediterranean wood-pasture landscapes with oak wood- lands as their characteristic habitats have not yet been studied at landscape scale. The present study aimed to fill these knowledge gaps by monitoring persistence and change of wood-pasture landscapes over a 50-year period, using Lesvos Island (Greece) as a case study. The specific research aims of the study were

(1) To quantify the land cover changes and transitions and to identify spatial hotspots of land change;

(2) To characterize structural landscape changes with the use of landscape and land cover metrics; and

(3) To assess oak woodland patch fragmentation and adjacencies as well as canopy cover as an indicator of oak woodland densities.

Building on the results of this landscape-level study, efforts to conserve and manage Eastern Mediterranean wood-pastures landscapes and their embedded oak woodlands could be targeted more effectively.

\section{Materials and Methods}

\section{Methodological Approach}

In order to address our research aims, a remote sensing approach was applied to two study areas at the center and the edge of approximate deciduous oak distribution on Lesvos Island (Fig. 1). The approach builds on two sets of aerial/satellite images spanning the time period between 1960 and 2010, complemented by socio-economic information on the study area. We studied a time period of 50 years, because we were interested in the long-term development and resilience of oak woodlands in the face of constant drivers of land-use change. This approach was partly dictated by the limited availability of aerial photographs between the 1970s and the 1990s for Lesvos Island, while other sources of data, e.g., Landsat imagery of this period, could not complement aerial and recent satellite images due to differences in resolution and scale.

In line with our research aims, we identified three fields of analysis: Changes in landscape composition, changes in landscape configuration, and specific oak woodland changes. In regard to landscape composition, we examined land cover patterns in 1960 and 2010 and land 
cover transitions, including the identification of spatial hotspots of change. Landscape configuration relates to the spatial arrangement, position, orientation, or shape complexity of patches on the landscape. Here, we included measures of fragmentation (the disruption of extensive habitats into small, isolated patches, Forman and Gordron 1986), interspersion, and landscape diversity in our analysis (Kennedy and Spies 2005). Specifically for the oak woodland class, we considered changes in canopy cover, adjacency, and fragmentation. Canopy cover is an important variable, as much of the biodiversity and ecosystem services provided by oak woodlands depend on a semi-open canopy cover (Garbarino and Bergmeier 2014). Fragmentation (expressed by indicators such as edge density, mean patch size, and largest patch index, Teixido et al. 2010) of Mediterranean oak woodland is also known to drastically alter a range of ecological functions and ecosystem services (Costa et al. 2014b). We included adjacency to neighboring land to assess potential pressures on oak woodlands. For example, we suspected that adjacent urban areas would exert stronger pressures on oak woodland than grass- and shrubland.

\section{The Study Sites}

The two study areas were located in the northwestern part of the island of Lesvos within the island's main distribution area of deciduous oaks (see Fig. 1, distribution area was approximated by combining land cover categories with potential occurrence of oaks from CORINE Land Cover 2010). The in situ rock of the area consists mainly of acid pyroclastic material, which forms relatively shallow and stony soils of the Cambisol type. The climate of the northern part of Lesvos is generally classified as accentuated thermo-mediterranean according to the xerothermic index. This is characterized by a relatively high level of precipitation in winter and very low precipitation during summer (Tselepidakis and Theoharatos 1989). Both municipalities are characterized by a geomorphological gradient from the mountain tops to the coast of the Aegean Sea and comprise several valleys with partly steep slopes. The main land cover types in northern Lesvos are oak wood- lands, grassand shrublands, pine forests, arable land (mostly in the form of complex cultivations), and olive groves. These vary across the area according to local differences in rainfall, elevation, and land-use management (Symeonakis et al. 2012). The oak woodlands in the area consist mainly of deciduous oak species with Quercus macrolepis L. dominating and intermingled with Q. pubescens Wild. as well as Q. cerris L. (Plieninger et al. 2011). Densities of the oak stands vary largely from closed to very open, savanna-like stands.

We selected the municipalities of Filia (FI, $39^{\circ} 150$ to $39^{\circ} 200 \mathrm{~N}, 26^{\circ} 050$ to $26^{\circ} 100 \mathrm{E}$; 2176 ha extent) and Mesotopos (ME, $39^{\circ} 060$ to $39^{\circ} 090 \mathrm{~N}, 25^{\circ} 590$ to $26^{\circ} 020 \mathrm{E}, 3855$ ha extent) for the in-depth study of land cover change as they represent typical examples of wood-pasture landscapes with relatively dense oak stands in the center (FI) and diminishing oak stands at the western edge (ME) of the overall oak distribution on the island, respectively (Fig. 1). The climate in ME (annual rainfall of $431 \mathrm{~mm}$, a mean annual temperature of $17.6{ }^{\circ} \mathrm{C}$ ) is dryer and hotter than in FI (508 mm, $\left.14.1^{\circ} \mathrm{C}\right)$. FI and ME have a similarly small populations with 690 and 980 inhabitants, respectively. However, population development has been different in the two villages with a $53.7 \%$ decline in the number of inhabitants between 1961 and 2001 in FI compared to $36.8 \%$ in ME (Table 1). In both municipalities, more than half of the economically active population consists of farmers. The demography of the respective farming populations differs significantly as only $18 \%$ of the farmers in ME compared with 45 
\% in FI are older than 65 years. In FI, there are 192 farms and a total of 8064 sheep in 2001, whereas in ME, there are 203 farms and 9168 sheep. The municipality area of ME is part of the 28.000 ha Special Protected Area (SPA, code GR4110010), which was designated in 2005 under the EU Wild Birds Directive.

\section{Data Sources, Land Cover Change Analysis, and Accuracy Assessment}

To analyze land cover change at the study sites, we generated two land cover maps in ArcGIS 10.0 for each study site with the first aerial photographs taken in the area in 1960 and recent satellite images from 2010. The panchromatic black- and-white aerial photographs from 1960 have a scale of 1:30,000 and were scanned at a resolution of $600 \mathrm{dpi}$ and geo-rectified using the Greek Coordinate system (GCS_GGRS_1987). The photographs for the whole island were taken by the Hellenic Air Force throughout 3 days in September 1960 using a 153.035 $\mathrm{mm}$ lens. Due to strategic military reasons, the coastline was blackened.

The ortho-rectified and cloud-free images from 2010 were produced by the WorldView-2 satellite in November 2010 with PSM 4-bands including an infrared color channel and a resolution of $1.85 \mathrm{~m}$. The classification of land cover on the aerial and satellite images was prepared by pre-mapping vegetation and land-use on the ground in both municipalities in spring 2010. According to the quality restrictions of the aerial photographs and supported by ground truthing, we distinguished the following eight land cover classes:

- $\quad$ Oak woodlands: Open to semi-open silvopastoral woodlands where deciduous oaks (Q. macrolepis, Q. cerris, and Q. pubescens) are dominant but accompanied by other woody species and phrygana and where tree density is [5 trees ha-1 (based on Costa et al. 2011),

- $\quad$ Riparian forests: Forest community along the banks of rivers and intermittently flowing streams that consist mainly of sycamore (Platanus orientalis L.) and an understory of evergreen shrub species like Rhododendron luteum L., Nerium oleander L., etc.,

- $\quad$ Pine forests: Coniferous forest community where Pinus brutia Ten. is dominant and with scattered P. nigra ssp. pallasiana; oaks and other deciduous trees may be intermingled in the canopy layer or present in the understory,

- $\quad$ Olive groves: Areas with cultivated olive trees (Olea europea L.) of different ages classes,

- Grass- and shrublands: Areas used as pastures or fallow land consisting of open grasslands, rough grasslands including rocky outcrops and bare ground, phrygana, and shrublands,

- Complex cultivation: Mosaic of irrigated and dryland arable fields with cereals, legumes fodder crops, etc., intensive grasslands, vines as well as tree rows and single trees on parcel boundaries and terrace edges,

- $\quad$ Urban areas: Built-up areas within and outside villages including home gardens and green urban sites as well as transport infrastructure with more than $10 \mathrm{~m}$ width, and

- $\quad$ Water areas: Non-vegetated water areas in rivers, small lakes, and along the coasts as well as gravel banks in intermittently flowing streams and sandy habitats along the coast. 
For each time period, a separate GIS polygon layer was constructed by digitizing areas as vector models on screen. According to the quality of the aerial photograph, we defined the minimum mapping unit at 0.25 ha and the minimum width for linear structures like roads and rivers at $10 \mathrm{~m}$. We started with the preparation of the 2010 time layer, which served as a baseline for adapting the digitalization of the 1960s aerial photographs. The classification accuracy of the 2010 land cover map was assessed by field comparison of 274 points within the two sampling sites in 2013. Sampling points for the accuracy assessment were systematically distributed along the intersections of a $1009100 \mathrm{~m}$ grid resulting in 100 and 174 points in FI and ME, respectively. Land cover was visually determined in the field according to the eight classes in close proximity to the sampling points without using the digitized land cover map or the satellite images. The total accuracy of the land cover classification using the WorldView-2 satellite images was $93 \%$ for both study sites (FI: $92 \%$, ME: 94 \%) (Foody 2002).

\section{Measurement of Dynamics in Oak Stands}

For a detailed analysis of stand dynamics, we used the constructed GIS to measure tree canopy cover within the oak woodland land cover class in the 2010 satellite images and the aerial photographs from 1960. We systematically placed a point-grid with a side length of 100 m over the whole area covered with oak woodlands in 2010 and 1960 in FI and ME (Carreiras et al. 2006). In our case, the gridbased approach was much more reliable for monitoring oak density dynamics in comparison with sampling designs that identify tree individuals in circular or rectangular study plots (Plieninger and Schaar 2008; de Waroux and Lambin 2012). This is because oak stands in large parts of FI were too dense to identify single tree individuals (especially from the lower quality 1960 aerial photos). In both study sites, the total area and the spatial distribution of oak woodlands varied due to land change processes between the two time layers. We therefore opted for a random starting point of the grid intersections in the oak woodland cover class, rather than investigating the same grid intersections for each time layer (because fixed grid intersections in 1960 could be located outside the oak woodland cover class in 2010). This procedure resulted in a total of 1691 (year 1960) and 1614 (year 2010) grid intersections for sampling in FI, and 537 (year 1960) and 580 (year 2010) in ME. At each grid intersection, we visually determined on a physiognomic and spectral basis if the point was overlapping with a tree canopy and a binary dataset (tree canopy: yes/no) was produced. We favored the visual analysis over an automated detection to avoid density biases due to shading effects induced by tree crowns or topography, and variable understory (bare soil, rocks, evergreen shrub, and dry grass) resulting in different spectral properties and structural physiognomies (Carreiras et al. 2006).

\section{Data Analyses}

Land cover composition was analyzed by calculating the number of patches, as well as the total and relative-as the percentage of the total area of a municipality-area of each land cover class for 1960 and 2010 directly from the polygon map in ArcGIS 10.0. Changes in composition between the two time layers were determined by calculating net losses or net gains for each land cover class in area and as percentage according to the original distribution of each class in 1960. To gain more information regarding loss or persistence of certain land cover classes, we generated transition matrices for each study site. We measured transition of 
land cover classes by intersecting the polygon maps from 1960 and 2010 and calculating the percentage change in each municipality area (Skalos et al. 2011). The transition analysis also made it possible to quantify the amount of area where land cover remained persistent or changed between the two points in time. A thorough assessment of land cover transitions is important for land change studies because the mere accounting of net changes is prone to ignoring land cover losses which have been compensated by gains in other parts of the studied sites (Pontius et al. 2004).

To analyze the impacts of land cover change in terms of fragmentation and heterogeneity on the landscape configuration of both municipalities, we applied indices of landscape metrics. We converted the polygon land cover map of each time layer to raster cells (1 m size) to calculate landscape metrics with the raster-based spatial pattern analysis software FRAGSTATS v4 (McGarigal et al. 2012). Common indices of landscape metrics to evaluate patch characteristics of land cover classes and especially forest patch fragmentation were determined for each study site and time layer (Kennedy and Spies 2005). At the level of land cover classes, number of patches (NP), mean patch size (MPS), largest patch index (LPI) as well as edge density (ED) were calculated. At the landscape level, we used different indices to measure fragmentation (NP, MPS, ED), interspersion with contagion index and interspersionjuxtaposition index, and diversity like Shannon diversity index and Evenness index. Additionally, we included the adjacency index for the patches of the oak woodland land cover class. This calculates the total km length of the edges of oak woodland patches shared with other land cover classes as well as their percentage of the total length (Teixido et al. 2010). We calculated the canopy cover of oak trees as a percentage of the total area occupied by the oak woodland land cover class for each study area and each time layer to characterize temporal dynamics within the oak stands (Carreiras et al. 2006).

\section{Results}

\section{Change in Land Cover Patterns}

In the two study sites-Filia (FI) in the heart and Mesotopos (ME) at the edge of the deciduous oak distribution - diverging and similar trends in land cover changes were observed within the 50-year study period (Table 2). In line with the approximate extent of oak woodlands on Lesvos Island (see Fig. 1), nearly three quarters of the municipality area of FI consisted of oak woodlands, whereas in ME open grass- and shrub-lands were dominant (Fig. 2). In FI, oak woodland area decreased at the center of oak distribution by $2 \%$, whereas in $\mathrm{ME}$, the area with oaks increased slightly at the edge of their distribution by $1.4 \%$ of the total municipality area. In contrast, the area of grass- and shrublands extended by $1.7 \%$ of the total area in FI, whereas it decreased by $3.6 \%$ in ME. Although it related to only $0.2 \%$ of the total area, the decrease of riparian forest area in ME was remarkable given that it amounted to 19 $\%$ of the initial area. In FI, a marginal increase in riparian forests was detected which amounted to $11 \%$ of the initial area.

Common patterns of land change in both municipalities over the study period were the significant extension of olive groves (FI: $1.7 \%$, ME $1.9 \%$ of the total area) as well as the expansion of urban areas (FI: $0.7 \%$; ME: $1.3 \%$, especially in the coastal strip). A similar trend was also observed for the development of complex cultivation areas over time: this land 
cover class decreased at both study sites (FI: -2.1; ME: -0.5). However, the dynamics of the former land change patterns and trends contrasted quite strongly between the study sites at the heart and the edge of oak distribution. The expansion of olive grove and urban areas was far more pronounced in ME with $249 \%$ and $291 \%$ of the initial area compared to only $28 \%$ and $96 \%$ in FI. Decreases in the complex cultivation class were less severe in ME with $-6 \%$ of the initial area than in FI with $-34 \%$.

\section{Dynamics of Landscape Change and Transition Analysis}

Both similar and contrasting trends in transitions between land cover classes were observed in the two study areas (Table 3). The land cover classes with the largest retained total area between 1960 and 2010 in FI were oak wood- lands (1494 ha) followed by grass- and shrublands (90.3 ha). In ME, grass- and shrublands (2523 ha) had the largest area of retention, followed by oak woodlands (285.3 ha). Detailed transition analysis in FI revealed complex conversion dynamics between the major land-use classes. Whereas a large proportion of oak stands (109.6 ha) were converted into grass- and shrublands in some parts of the study site, in other parts, the contrary was observed and a considerable area of grass- and shrubland (78.4 ha) has been transformed into oak woodlands during the last 50 years. Mostly, monodirectional changes in FI have been the conversion of complex cultivation into either oak woodlands (33.9 ha) or urban areas (9.3 ha), as well as the transition of oak woodlands (44.8 ha), riparian forests (5.1 ha), and complex cultivation (6.6 ha) into olive groves. Spatial hotspots of oak woodland area loss in FI were the valley slopes-mostly due to olive grove expansions-along the north-flowing creek, whereas there have been area gains in the hilly region near the urban center (Fig. 3).

The dynamic character of land cover changes between the major land cover classes was also evident in ME, although in contrast to FI, a net conversion of grass- and shrublands into forests was detected. In some parts of the study site, grass- and shrublands (251.2 ha) have been converted into oak woodlands, while in other parts, oak stands (179.7 ha) have been transformed into grass- and shrublands. Other major processes in ME have been the transition of complex cultivation (47.9 ha), grass- and shrublands (22.7 ha), and oak woodlands (14.9 ha) into olive groves, as well as the conversion of grass- and shrublands (27.2 ha) and complex cultivation (16.2 ha) into urban areas. Conversions that are minor in terms of area but relevant to the land cover classes concerned were the transition of riparian forests into grass- and shrublands (7.9 ha) and complex cultivation (3.3 ha). Major hotspots of oak woodland area loss in ME have been the slopes and bottoms of the creek valleys as well as the immediate surroundings of the urban agglomerations, whereas considerable area gains were concentrated in the remote and mountainous areas in the northern and western parts of the municipality (Fig. 3).

\section{Changes in Landscape Configuration and Land Cover Class Metrics}

In both study sites, the spatial configuration and fragmentation of the landscape changed considerably between 1960 and 2010. Mean patch size decreased in FI from $5.8( \pm 69.6)$ to 3.3 ( \pm 62.6$)$ by nearly $50 \%$ and in ME from $6.1( \pm 65.3)$ to $3.9( \pm 39.1)$ by approximately onethird. The number of patches increased by 274 (1960: 374; 2010: 658) and 354 (1960: 643; 2010: 997) in FI and ME, respectively. Moreover, edge density in FI increased by $52.8 \mathrm{~m}$ ha-1 
(1960: $70.4 \mathrm{~m}$ ha-1; 2010: $123.2 \mathrm{~m}$ ha-1) and in ME by $54.8 \mathrm{~m}$ ha-1 (1960: $87.6 \mathrm{~m}$ ha-1; 2010: $142.4 \mathrm{~m}$ ha-1).

Measures of interspersion identified lower percentages in 2010 (e.g., interspersionjuxtaposition index FI: 40.3 \%; ME: 60.0 \%) than in 1960 (FI: $52.2 \%$; ME: $68.1 \%$ ) for both study sites indicating an increasing clumpy aggregation and higher dispersion of the patch classes. The generally smaller patch sizes combined with the increasing complexity of spatial aggregation resulted in higher values of landscape diversity parameters in 2010 (e.g., Shannon index FI: 0.94; ME: 0.96) compared to 1960 (FI: 0.88; ME: 0.84).

Except for riparian forests (FI, ME) and complex cultivation (FI), the number of patches increased for all land cover classes in both municipalities during the study period (Table 4). In contrast, a significant decline in the mean patch sizes of all land cover classes except for urban areas (FI, ME) and olive groves (ME) was detected. As a consequence, edge density increased for nearly all land cover classes. However, the most significant changes in edge densities were observed for oak woodlands with an increase of $16.9 \mathrm{~m}$ ha-1 in FI and $18 \mathrm{~m}$ ha1 in ME, and for grass- and shrublands with $30.3 \mathrm{~m}$ ha- 1 in FI and $27.4 \mathrm{~m}$ ha- 1 in ME. The largest patch index did not vary considerably for most land cover classes between 1960 and 2010 (Table 4). However, in contrast to the trend towards smaller mean patch sizes, the LPI of oak woodlands did increase by nearly $5 \%$ in FI, whereas it remained constant for oak stands in ME.

\section{Fragmentation of Oak Woodlands and Development of Canopy Cover}

Due to the higher edge densities, the total adjacency index of oak woodlands in both municipalities also increased by $78 \%$ in FI and $93 \%$ in ME from 1960 to 2010 (Table 5). In 1960, the most common land cover classes adjacent to oak woodlands were grass- and shrublands and complex cultivations, whereas adjacencies to olive groves and urban areas were far less frequent. By 2010, there had been a substantial increase in adjacency of oak woodlands to urban areas (quadrupling the relative length since 1960), to grass- and shrublands (doubling the length since 1960), and to olive groves (quadrupling the length since 1960, at least in ME). In contrast, the vicinity of oak woodlands to complex cultivation decreased considerably in both municipalities.

The trend towards a more fragmented landscape pattern in 2010 was also obvious in the detailed patch analysis of the oak woodlands, but with remarkable differences between the two study sites (Fig. 4). Generally, the number of oak patches in the size class under 1 ha increased from 1960 to 2010 in both municipalities, whereas the patch number decreased especially in the size classes between 1 ha and 10 ha and to a lesser degree between 10 and 100 ha. In ME, the area covered by oak patches under 10 ha, and especially under 1 ha, increased by 87 ha from 1960 to 2010. In contrast, the largest oak patch in FI extended its area — as indicated already by the higher LPI value-by more than 300 ha due to land cover change of complex cultivation and riparian forests to oak woodlands in the western proximities of the urban center (Fig. 3). In FI, oak woodland area in very small patches under 1 ha also increased.

The point-grid analysis within oak woodland patches revealed a significant increase in canopy cover between 1960 and 2010 in both communities (Fig. 5). In FI, canopy cover increased in 
oak patches by $9.1 \%$ from $49.6 \%$ in 1960 to $58.7 \%$ in 2010. Canopy cover was generally lower in ME, but increased by 8.1 \% in a similar manner to FI (1960: 34.8 \%, 2010: 42.9 \%).

\section{Discussion}

\section{Changes in Major Land Cover Classes and Underlying Driving Forces}

While some common land change trends were observed in the wood-pasture landscapes of both study areas, we also detected a diverging development trend for the oak woodland land cover class. Unlike in other land change studies in Mediterranean countries, the general land cover classes in our case study areas remained the same and no new forest types like Eucalypt or Pine plantations or big infrastructure projects like water reservoirs evolved (Teixido et al. 2010; Costa et al. 2011).

The shift from the traditional multifunctional agrosilvopastoral land-use systems with extended areas of terraced arable fields to a pure livestock grazing system since the 1960s was observed in many parts in the Eastern Aegean (Plieninger et al. 2011; Tzanopoulos and Vogiatzakis 2011). In our case study, this land-use change led to an abandonment of arable farming and a sharp decline in complex cultivation patterns in many parts of the municipalities. Developments in agricultural productivity and policy combined with rural depopulation affected the profitability of island agriculture more severely than mainland agriculture (Petanidou et al. 2008). Many island farms were specialized in livestock production systems with sheep and goats, thanks to the less laborious production systems and the profitable livestock head payments of EU Common Agricultural Policy (Kizos et al. 2013). Arable fields on terraces in hilly and mountainous spots were more often abandoned than fields in flat zones and close to water streams (Papanastasis 2007), which explains the stronger decline of complex cultivation area in Filia (FI) in comparison with Mesotopos (ME). Today, complex cultivation in ME consists mostly of animal feed crops or garden vegetables, whereas in FI, the decreasing cultivated areas are also used for vines.

Olive groves expanded in both study areas, although the hotspot of olive production is in the southeastern part of Lesvos Island ("olive zone”) (Kizos and Koulouri 2006). On Lesvos, the olive industry with its high quality oils and related products is still a major economic factor as it contributes between 3 and $4 \%$ of the GDP (according to data of the Hellenic statistical authority for the year 2010). The growing demand for high-quality olive oils and the generally co-operative-based olive mill businesses have driven the expansion of the olive grove area even in major "grazing zones" like FI and ME, despite the fact that in some parts of the island, a number of olive plantations were also abandoned. In ME, olive groves replaced mostly complex cultivation patches in the flat valley bottoms of the municipality, whereas in FI, riparian forests and oak woodlands were converted to olive groves due to water availability as well as pre-existing terraces from old fields. Loumou et al. (2000) found a close relationship between olive grove maintenance/expansion and touristic development at the municipal level. In contrast, our results showed that an increase in olive grove area also occurred outside the main touristic centers in our case study municipalities. Urban area expanded during the studied period, although the population size decreased in FI by approximately $54 \%$ and in ME by $37 \%$ (Table 1). One reason for this is the construction of stables, forage repositories, and other livestock infrastructure, which was necessary to support 
the intensified grazing practices with sheep and goats (Kizos et al. 2013). Although they are not located within a touristic hotspot on the island, urban sprawl in the study sites was also influenced by a general growth in tourism on Lesvos and the related spread of second and holiday homes that was also observed on other islands of the Aegean (Coccossis and Constantoglou 2005; Detsis et al. 2010). With a larger coastal area suitable for touristic uses, urban sprawl was much more pronounced in ME, where mostly former grass- and shrublands and complex cultivation areas have been converted.

Unlike other studies of oak stand development in the Mediterranean (Costa et al. 2011; Kouba and Alados 2012), we could not confirm a decreasing oak woodland area during the last 50 years in our two study areas. Instead we observed a growth in oak woodland area at the edge of deciduous oak distribution in ME totaling $10 \%$ of the initial area. The loss of oak woodland area in FI which amounted to approximately $3 \%$ of the initial area was also less pronounced than in other wood-pasture landscapes of the Mediterranean with evergreen or deciduous oak woodlands being used by agroforestry systems (Plieninger 2006; Ales et al. 1992; Teixido et al. 2010). We conclude that the parallel processes of abandonment of crop cultivation and intensification of livestock grazing have generally been beneficial rather than damaging in terms of oak woodland extent and cover density. Obviously, crop cultivation could have been a more serious constraint on woodland expansion in our study sites than suspected.

However, spatiotemporal dynamics were very heterogeneous in the area development of oak woodlands in our studied municipalities. Land cover transitions-involving gains and losses for oak stands-have been especially intensive with grass- and shrublands and to a lesser degree with olive groves. These results indicate that the intensified sheep and goat grazing did not apply uniformly to the whole oak woodland area within the studied municipalities. Rather, some parts of the oak stands around the urban centers and livestock farms and stables have been con- verted by heavy year-round grazing, whereas other more remote and mountainous areas were only periodically grazed or largely abandoned resulting in regenerating and expanding oak stands. From 1961 to 2000, the number of farms decreased drastically by $53 \%$ in FI and $44 \%$ in ME, indicating a spatially very irregular grazing management in the municipalities (Kizos et al. 2013). The expansion of oak woodland area in ME could be linked to a less intensive growth in sheep numbers (66 \% in ME vs. $103 \%$ in FI, see Table 1) with a generally lower livestock stocking rate per ha municipality area (2.3 sheep per ha in ME in 2001, 3.7 sheep per ha in FI) and a decrease in Utilized Agricultural Area between 1961 and 2001 (-15 \% in ME vs. an increase of $8 \%$ in FI). Topography-characterized by oak woodlands expanding into very steep and rocky slopes mainly in the northern parts of the municipality_ could also play a role in the expansion of oak woodland.

\section{Impacts on Landscape Configuration}

In quantitative terms, the most important type of land change between 1960 and 2010 in our studied municipalities in the Eastern Mediterranean was a higher spatial heterogeneity of land cover and an increased landscape diversity. This development trend towards more heterogeneous and fragmented landscapes during the last 50 years was also observed in other Eastern Mediterranean cultural landscapes (Detsis et al. 2010) and is similar to other Mediterranean wood-pasture regions such as Portugal's cork woodlands (Costa et al. 2009) and Spanish holm oak dehesas (Plieninger 2006) or oak forests in the Spanish Pyrenees 
(Kouba and Alados 2012). In our case, the direct drivers of lower mean patch areas and higher edge densities for the main land cover classes were the opposing developments of intensification of livestock grazing in some parts and the abandonment of any regular landuses in other parts of the municipality combined with the growing significance of olive production and urbanization.

Increasing heterogeneity within the wood-pasture landscapes as indicated by higher edge density and lower measures of interspersion indices is also the result of a municipality area shared by many private owners with relatively small land parcels (Kizos et al. 2013). Land ownership has been identified as an important underlying driving force for management and diversity in temperate forest ecosystems, and small-scale land ownership in particular led to a heterogeneous management mosaic corresponding with the different goals of the respective owners (Schaich and Plieninger 2013). Although the underlying driving forces and the resulting land-use transformations were very similar in the dehesa landscapes with ever- green oaks in Spain, the large privately owned estates there obviously mitigated a rapid landscape fragmentation (Plieninger 2006). Edge densities in our case study municipalities on Lesvos were considerably higher (123-142 m ha-1) than in Spanish municipalities with large dehesa land holdings (25-29 m ha-1) (see Plieninger 2006), but still significantly lower than on other Aegean Islands with higher population densities and rates of urbanization than in our area (214 m ha-1) (see Tzanopoulos and Vogiatzakis 2011).

\section{Dynamics of Oak Woodland Pattern and Density}

In contrast to other studies on oak forest and woodland dynamics in the Mediterranean (Teixido et al. 2010; Kouba and Alados 2012), the decrease in the woodland area in the core zone of Q. macrolepis population was less pronounced and we even detected a net gain in oak woodland area at the edge of species distribution in northern Lesvos. Particularly at the edge of oak distribution in the northwestern region of Lesvos where the climate is becoming dryer due to climate change (Korner et al. 2005) and soils more eroded due to intensive agriculture and grazing in the past (Marathianou et al. 2000), expanding oak stands are a positive development for the conservation of deciduous oak woodland habitats and complex woodpasture landscapes. However, the strong oak woodland area dynamics indicate that intensive livestock grazing as the currently dominant form of land-use as well as increasing livestock numbers is not sustainable. Stand-level studies of oak regeneration in Mediterranean woodlands have demonstrated a clear correlation between grazing indicators and oak seedling and sapling numbers (Plieninger et al. 2004, 2011; Dufour-Dror 2007). A spatially very heterogeneous and largely non-systematic grazing system-due to small land properties and often unclear ownership, thanks to the lack of a land cadastral system in Greece-leads to an oak woodland regression in intensively used areas and an oak expansion in largely abandoned parts of the case study areas. Site factors like soil fertility and water availability did not prove to be equally important for explaining this land-use transition which contrasts with other Mediterranean regions (Moreira et al. 2001; Vos 1993).

Similar to what has been found in Italian and Spanish mountain landscapes (Geri et al. 2010; Lasanta-Martinez et al. 2005), increases in woodland areas mainly occurred via successional processes following land abandonment in grass- and shrublands and — to a minor degree - in complex cultivation and olive groves. The expanding oak woodlands increased the structural diversity of landscapes containing predominantly grass- and shrublands that occur at the edge 
of oak distribution. Although oak patch sizes generally shrunk, the evolving tree structures offer habitats and food resources to small mammals, birds, and arthropods, and provide ecosystem services like soil protection and climate regulation (Marathianou et al. 2000). In the core zone of oak distribution, the increasing adjacencies between oak woodland and grassand shrubland patches indicated a more extensive occurrence of ecotones and transitional stages. This development could be beneficial for species that demand complex habitat structures and edge structures like Hermann's tortoise and other species of the terrestrial herpetofauna (Rozylowicz and Popescu 2013). However, it could be less desirable for forest species because the core forest area decreases and habitats become more fragmented (Moreira and Russo 2007; Brotons and Herrando 2001). Whereas the number of small patches under 1 ha increased, the percentage of area in patches bigger than 1000 ha also increased in FI from app. $80 \%$ to $95 \%$. So developments in oak woodland patterns over time also revealed contrasting trends: fragmentation in some parts and homogenization in other parts of the case study areas. The woodland gains filled some gaps, thereby increasing the size of the largest oak patch and hence connectivity for this habitat type. On Sifnos Island, a similar homogenization of the core habitat type of maquis with Juniperus phoenicea was observed in abandoned areas, whereas other more urban areas became more heterogeneous (Tzanopoulos and Vogiatzakis 2011).

To complement our land change study, we analyzed oak woodland canopy cover because forest development and degradation over time can only be evaluated consistently if stand structure is considered (Rautiainen et al. 2011). This is especially important for dry semi-open Mediterranean woodlands where land-use changes often lead to subtle changes in stand structure rather than to complete woodland clearances (Barbero et al. 1990). Contrary to our as- sumption that oak stands are mere legacies of the former traditional land-use systembased on a former study that detected scarce oak regeneration using a stand-level sampling approach in the area (Plieninger et al. 2011)—we identified significant canopy cover increases in oak stands within both study areas in this landscape-level study. This is especially remarkable given that the lower quality of the aerial photos (shade effects, lower contrast) would most likely lead to an overestimation of oak canopy cover in the 1960s. Thus, canopy cover increases were under rather than overestimated. This situation contrasts with findings from other parts of the Mediterranean basin, where considerable tree density declines have been detected, for example, in argan woodlands of Morocco (de Waroux and Lambin 2012) and dehesa woodlands with evergreen Q. ilex in Spain (Plieninger and Schaar 2008).

Recovering oak densities even at the edge of their distribution may also indicate a higher resilience to human disturbances and deteriorating climate and site factors of deciduous oak woodland ecosystems in wood-pasture landscapes than has been suspected by other authors (Barbero et al. 1990). It is also an indication that the edge of oak distribution in Lesvos is caused by anthropogenic factors rather than by climatic factors and that the traditional agrosilvopastoral systems with crop cultivation- e.g., arable fields in terraced semi-open oak stands-have been obviously more detrimental to oak regeneration than supposed. Deciduous oak stands on Lesvos seem to cope better with spatiotemporally irregular human disturbances like overgrazing, firewood cutting, etc., than with frequent regular disturbances like agriculture. However, growing biomass in abandoned oak woodland patches can increase the frequency of wild fire. Oak stand recovery is particularly slow after intensive and regular fires because of slow sprout production and difficult seed spreading. Our study areas have not been 
subjected to large and frequent wildfires during recent decades (Koutsidou et al. 2006), a fact that might also have favored the positive oak density developments.

\section{Conclusion}

Our study in wood-pasture landscapes of northern Lesvos showed that deciduous oak woodlands were generally stable in area and densities over the course of a 50-year period. At the same time, it highlighted the spatiotemporal dynamics of land cover change, especially the dynamics of oak woodland patterns as a consequence of changes in the land-use system from an agrosilvopastoral to a mere grazing system. The parallel and spatially irregular processes of abandonment of crop cultivation and intensification of grazing led to an opposite transition of oak woodlands with area expansion and loss in different parts, and surprisingly to a general increase in oak stand densities. All in all, a more heterogeneous landscape evolved, which could not only be judged negatively_especially with expanding oak woodland patches in landscapes generally dominated by grass- and shruband-in terms of biodiversity conservation and ecosystem services provisioning.

Recent policy and socio-economic developments at the European and the regional level seem to represent similar driving forces for the continuation of the recorded trends. As such, the results of this study do not guarantee the future persistence of semi-open Q. macrolepis woodlands and other richly structured wood-pasture landscapes as they are dependent on global socio-economic driving forces as well as on regional responses to these. In view of the still increasing numbers of livestock to compensate for market price decreases and intensified wood cutting activities due to the economic crisis in Greece, land-use intensification in municipalities with active farmers will continue. On the other hand, a general "return" to rural areas and farming, especially sheep farming, does not appear to be very likely despite the crisis, which means that in municipalities, land abandonment will also continue. At the same time, the reformed EU Common Agricultural Policy still ignores wood-pastures and there is a clear danger that denser oak plots will not be considered eligible as grazing lands to ensure subsidies (via area-related direct payments) for sheep farmers if the area consists more than 30 \% of so called "forest-species." The same is true for the EU Habitat Directive, where anthropogenic habitats like many semi-open silvopastoral oak woodlands are not specifically listed as habitat of common conservation interest despite their extraordinary biodiversity, or the Natura 2000 evaluation schemes of naturalness do not correspond with their structure and origin. There seems to be a greater issue at stake here: how more complex management systems that incorporate different structural aspects and land covers according to standard classifications (e.g., "forest," "shrubland”) can be included in rural development and conservation policies that seek to integrate the provision of ecosystem services, biodiversity, and an economic land-use activity that is viable financially.

Wood-pasture landscapes and especially oak woodlands in the Mediterranean and continental Europe are at the center of this debate between land cover types and land-use practices, literally at the interface between largely dense forests and grass- and shrublands. To secure their outstanding biodiversity, ecosystem services, and cultural heritage, multifunctional silvopastoral oak woodlands should be actively promoted in EU agricultural policy development and their complexity must be grasped at the regional level via specific agrienvironmental measures, Natura 2000 management plans, and extension services for farmers in order to steer land-use management more effectively. 


\section{Acknowledgements}

This research was supported by IKYDA, an integrated action program between the German Academic Exchange Service (DAAD) and the Greek State Scholarship Foundation (I.K.Y). Additional funding was provided through grants 613520 (Project AGFORWARD) and 603447 (Project HERCULES) from the European Commission (7th Framework Program). We are very grateful to Sotiros Koukoulas (University of the Aegean) for providing access to the 1960 aerial images, to Konstantina Lagkou for supporting accuracy assessment in the field, and to Emily Kilham for improving the language of this paper. 


\section{References}

Ales RF, Martin A, Ortega F, Ales EE (1992) Recent changes in landscape structure and function in a Mediterranean region of Sw Spain (1950-1984). Landsc Ecol 7(1):3-18. doi:10.1007/ Bf02573953

Arhonditsis G, Giourga C, Loumou A (2000) Ecological patterns and comparative nutrient dynamics of natural and agricultural Mediterranean-type ecosystems. Environ Manage 26(5): 527-537. doi:10.1007/s002670010110

Arianoutsou-Faraggitaki M (1985) Desertification by overgrazing in Greece - the case of Lesvos Island. J Arid Environ 9:237-242

Bakker MM, Govers G, Kosmas C, Vanacker V, van Oost K, Rounsevell M (2005) Soil erosion as a driver of land-use change. Agr Ecosyst Environ 105(3):467-481. doi:10.1016/j.agee.2004. 07.009

Barbero M, Bonin G, Loisel R, Quezel P (1990) Changes and disturbances of forest ecosystems caused by human activities in the western part of the Mediterranean basin. Vegetatio 87(2):151-173. doi:10.1007/Bf00042952

Bergmeier E, Petermann J, Schro"der E (2010) Geobotanical survey of wood-pasture habitats in Europe: diversity, threats and conservation. Biodivers Conserv 19(11):2995-3014. doi:10.1007/s10531- 010-9872-3

Brotons L, Herrando S (2001) Factors affecting bird communities in fragments of secondary pine forests in the north-western Mediterranean basin. Acta Oecol 22(1):21-31. doi:10.1016/ S1146-609x(00)01095-X

Campos P, Huntsinger L, Oviedo JL, Starrs PF (2013) Mediterranean oak woodland working landscapes. Springer, New York

Carreiras JMB, Pereira JMC, Pereira JS (2006) Estimation of tree canopy cover in evergreen oak woodlands using remote sensing. Forest Ecol Manag 223(1-3):45-53. doi:10.1016/j.foreco.2005. 10.056

Coccossis H, Constantoglou ME (2005) The need of spatial typologies in tourism planning and policy making: the Greek case. In: Vrije Universiteit Amsterdam (ed) 45th Congress of the European Regional Science Association, "Land Use and Water Management in a Sustainable Network Society”. Amsterdam, pp 1-20 
Costa A, Pereira H, Madeira M (2009) Landscape dynamics in endangered cork oak woodlands in Southwestern Portugal (1958-2005). Agrofor Syst 77(2):83-96. doi:10.1007/s10457-

009-9212-3

Costa A, Madeira M, Santos JL, Oliveira A (2011) Change and dynamics in Mediterranean evergreen oak woodlands landscapes of Southwestern Iberian Peninsula. Landscape Urban Plan 102(3):164-176. doi:10.1016/j.landurbplan.2011.04.002

Costa A, Madeira M, Lima Santos J, Plieninger T (2014a) Recent dynamics of evergreen oak wood-pastures in South-western Iberia. In: Hartel T, Plieninger T (eds) European woodpastures in transition: a social-ecological approach. Earthscan from Routledge, Abingdon, New York, pp 70-89

Costa A, Madeira M, Lima Santos J, Plieninger T, Seixas J (2014b) Fragmentation patterns of evergreen oak woodlands in Southwestern Iberia: Identifying key spatial indicators. J Environ Manag 133:18-26. doi:10.1016/j.jenvman.2013.11.026

de Waroux YL, Lambin EF (2012) Monitoring degradation in arid and semi-arid forests and woodlands: the case of the argan woodlands (Morocco). Appl Geogr 32(2):777-786. doi:10.1016/ j.apgeog.2011.08.005

Detsis V, Ntasiopoulou G, Chalkias C, Efthimiou G (2010) Recent insular mediterranean landscape evolution: a case study on Syros, Greece. Landsc Res 35(3):361-381. doi:10.1080/ 01426391003746549

Dikou A, Papapanagiotou E, Troumbis A (2011) Integrating landscape ecology and geoinformatics to decipher landscape dynamics for regional planning. Environ Manag 48(3):523-538. doi:10.1007/s00267-011-9714-4

Dufour-Dror JM (2007) Influence of cattle grazing on the density of oak seedlings and saplings in a Tabor oak forest in Israel. Acta Oecol 31(2):223-228. doi:10.1016/j.actao.2006.11.003

ESYE (1964) Apotelesmata apografis georgias-ktinotrofias 1961. http://www.statistics.gr/ (in Greek)

ESYE (2001) Apotelesmata apografis georgias-ktinotrofias 2000-2001. http://www.statistics.gr/ (in Greek) 
Foody GM (2002) Status of land cover classification accuracy assessment. Remote Sens Environ 80(1):185-201. doi:10.1016/ S0034-4257(01)00295-4

Forman RTT, Gordron M (1986) Landscape Ecology. Wiley, New York

Garbarino M, Bergmeier E (2014) Plant and vegetation diversity in European wood-pastures. In: Hartel T, Plieninger T (eds) European wood-pastures in transition: a social-ecological approach. Earthscan from Routledge, Abingdon, New York, pp 113-131

Geri F, Amici V, Rocchini D (2010) Human activity impact on the heterogeneity of a Mediterranean landscape. Appl Geogr 30(3):370-379. doi:10.1016/j.apgeog.2009.10.006

Grove AT, Rackham O (2001) The nature of mediterranean europe: an ecological history. Yale University Press, New Haven, London

Iosifides T, Politidis T (2005) Socio-economic dynamics, local development and desertification in Western Lesvos, Greece. Local Env 10:487-499

Kalabokidis K, Iosifides T, Henderson M, Morehouse B (2008) Wildfire policy and use of science in the context of a socio- ecological system on the Aegean Archipelago. Environ Sci Policy 11(5):408-421. doi:10.1016/j.envsci.2008.01.006

Kennedy RSH, Spies TA (2005) Dynamics of hardwood patches in a conifer matrix: 54 years of change in a forested landscape in Coastal Oregon, USA. Biol Conserv 122(3):363-374. doi:10. 1016/j.biocon.2004.07.022

Kizos T, Koulouri M (2006) Agricultural landscape dynamics in the Mediterranean: Lesvos (Greece) case study using evidence from the last three centuries. Environ Sci Policy 9(4):330342. doi:10. 1016/j.envsci.2006.02.002

Kizos T, Plieninger T, Schaich H (2013) “Instead of 40 sheep there are 400': traditional grazing practices and landscape change in western Lesvos, Greece. Landscape Res 38(4):476498. doi:10. 1080/01426397.2013.783905

Körner C, Sarris D, Christodoulakis D (2005) Long-term increase in climatic dryness in the East-Mediterranean as evidenced for the island of Samos. Reg Environ Change 5(1):27-36. doi:10.1007/ s10113-004-0091-x

Kosmas C, Danalatos NG, Gerontidis S (2000a) The effect of land parameters on vegetation performance and degree of erosion under Mediterranean conditions. Catena 40(1):3-17. doi:10. 1016/S0341-8162(99)00061-2 
Kosmas C, Gerontidis S, Marathianou M (2000b) The effect of land use change on soils and vegetation over various lithological formations on Lesvos (Greece). Catena 40(1):51-68. doi:10. 1016/S0341-8162(99)00064-8

Kouba Y, Alados CL (2012) Spatio-temporal dynamics of Quercus faginea forests in the Spanish Central Pre-Pyrenees. Eur J Forest Res 131(2):369-379. doi:10.1007/s10342-0110509-1

Koutsidou E, Panidi K, Margaris NS (2006) Effects of grazing and fires on biodiversity of oak forest rangeland in W. Lesvos. In: P. V, Papanastasis Z, Parisi M (eds) Range Science of xerothermic Areas-Proceedings of the 5th Panhellenic Rangeland Congress Heraclion of Crete. Hellenic Range and Pasture Society, Heraklion, pp 65-73

Lasanta-Martinez T, Vicente-Serrano SM, Cuadrat-Prats JM (2005) Mountain Mediterranean landscape evolution caused by the abandonment of traditional primary activities: a study of the Spanish Central Pyrenees. Appl Geogr 25(1):47-65. doi:10. 1016/j.apgeog.2004.11.001

Loumou A, Giourga C, Dimitrakopoulos P, Koukoulas S (2000) Tourism contribution to agro-ecosystems conservation: the case of Lesbos Island, Greece. Environ Manage 26(4):363-370. doi:10.1007/s002670010093

Marathianou M, Kosmas C, Gerontidis S, Detsis V (2000) Land-use evolution and degradation in Lesvos (Greece): a historical approach. Land Degrad Dev 11(1):63-73. doi:10.1002/ (Sici)1099-145x

McGarigal K, Cushman SA, Ene E (2012) FRAGSTATS v4: Spatial Pattern Analysis Program for Categorical and Continuous Maps. Computer software program produced by the authors at the University of Massachusetts, Amherst. http://www.umass.edu/ landeco/research/fragstats/fragstats.html

Moreira F, Russo D (2007) Modelling the impact of agricultural abandonment and wildfires on vertebrate diversity in Mediterranean Europe. Landsc Ecol 22(10):1461-1476. doi:10.1007/ s10980-007-9125-3

Moreira F, Rego FC, Ferreira PG (2001) Temporal (1958-1995) pattern of change in a cultural landscape of northwestern Portugal: implications for fire occurrence. Landsc Ecol 16(6):557-567. doi:10.1023/A:1013130528470

Oppermann R, Beaufoy G, Jones G (2012) High nature value farming in Europe - 35 European Countries. Verlag Regionalkultur, Ubstadt-Weiher, Experiences and Perspectives 
Papanastasis VP (2007) Land abandonment and old field dynamics in Greece. In: Cramer VA, Hobbs RJ (eds) Old fields: dynamics and restoration of abandoned Farmland. Island Press, Washing- ton DC, pp 225-246

Petanidou T, Kizos T, Soulakellis N (2008) Socioeconomic dimen- sions of changes in the agricultural landscape of the Mediterranean basin: a case study of the abandonment of cultivation terraces on Nisyros Island, Greece. Environ Manag 41(2):250-266. doi:10.1007/s00267-007-9054-6

Plieninger T (2006) Habitat loss, fragmentation, and alteration - Quantifying the impact of land-use changes on a Spanish dehesa landscape by use of aerial photography and GIS. Landsc Ecol 21(1):91-105. doi:10.1007/s10980-005-8294-1

Plieninger T, Schaar M (2008) Modification of land cover in a traditional agroforestry system in Spain: processes of tree expansion and regression. Ecol Soc 13(2):25

Plieninger T, Pulido FJ, Schaich H (2004) Effects of land-use and landscape structure on holm oak recruitment and regeneration at farm level in Quercus ilex L. dehesas. J Arid Environ 57(3):345-364. doi:10.1016/S0140-1963(03)00103-4

Plieninger T, Schaich H, Kizos T (2011) Land-use legacies in the forest structure of silvopastoral oak woodlands in the Eastern Mediterranean. Reg Environ Change 11(3):603615. doi:10. 1007/s10113-010-0192-7

Pontius RG, Shusas E, McEachern M (2004) Detecting important categorical land changes while accounting for persistence. Agr Ecosyst Environ 101(2-3):251-268. doi:10.1016/j.agee.2003.09. 008

Rautiainen A, Wernick I, Waggoner PE, Ausubel JH, Kauppi PE (2011) A national and international analysis of changing forest density. PLoS One 6(5):e19577. doi:10.1371/journal.pone. 0019577

Rozylowicz L, Popescu VD (2013) Habitat selection and movement ecology of eastern Hermann's tortoises in a rural Romanian landscape. Eur J Wildl Res 59(1):47-55. doi:10.1007/s10344- 012-0646-y

Schaich H, Plieninger T (2013) Land ownership drives stand structure and carbon storage of deciduous temperate forests. For Ecol Manag 305:146-157. doi:10.1016/j.foreco.2013.05.013 
Schaich H, Plieninger T, Konold W (2004) Structural elements of the traditional dehesa landscape in Spain and their importance for nature conservation and rural development. Berichte der Naturforschenden Gesellschaft Freiburg i Br 94:93-125

Skalos J, Weber M, Lipsky Z, Trpakova I, Santruckova M, Uhlirova L, Kukla P (2011) Using old military survey maps and orthophotograph maps to analyse long-term land cover changes Case study (Czech Republic). Appl Geogr 31(2):426-438. doi:10.1016/j.apgeog.2010.10.004

Symeonakis E, Caccetta P, Koukoulas S, Furby S, Karathanasis N (2012) Multi-temporal land-cover classification and change analysis with conditional probability networks: the case of Lesvos Island (Greece). Int J Remote Sens 33(13):4075-4093. doi:10.1080/01431161.2011.640961

Teixido AL, Quintanilla LG, Carreno F, Gutierrez D (2010) Impacts of changes in land use and fragmentation patterns on Atlantic coastal forests in northern Spain. J Environ Manage 91(4):879-886. doi:10.1016/j.jenvman.2009.11.004

Tsadila E, Evangelou L, Tsadilas C, Giourga C, Stamatiadis S (2012) Land-use effect on selected soil quality parameters. Commun Soil Sci Plant Anal 43(3):595-604. doi:10.1080/00103624.2012. 639109

Tselepidakis IG, Theoharatos GA (1989) A bioclimatic classification of the Greek area. Theor Appl Climatol 40:147-153

Tzanopoulos J, Vogiatzakis IN (2011) Processes and patterns of landscape change on a small Aegean island: the case of Sifnos, Greece. Landsc Urban Plan 99(1):58-64. doi:10.1016/j.land urbplan.2010.08.014

Vos W (1993) Recent landscape transformation in the tuscan apennines caused by changing land-use. Landsc Urban Plan 24(1-4):63-68. doi:10.1016/0169-2046(93)90084-Q 


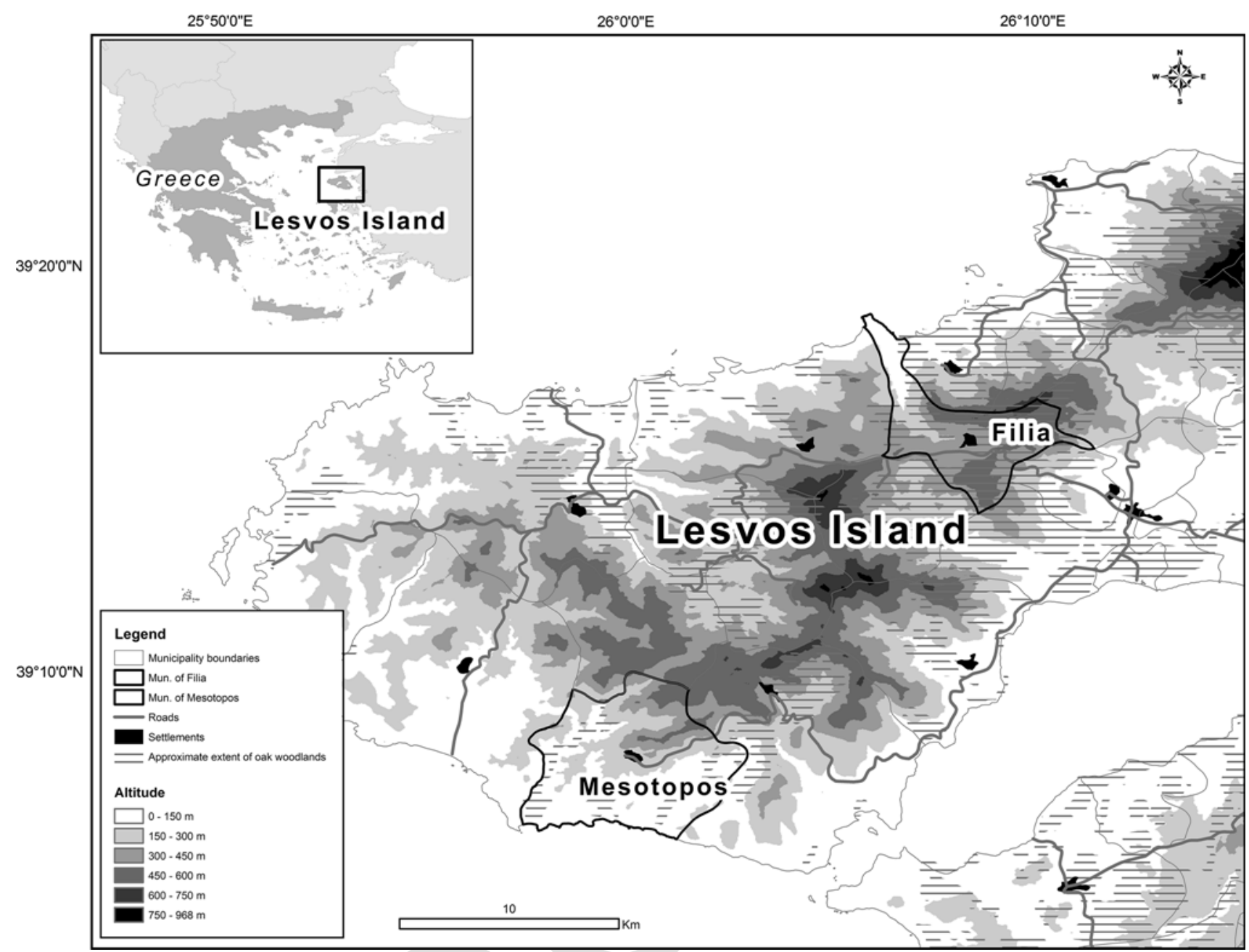

Fig. 1 Location of the two studied municipalities “Filia"' and "Mesotopos" and approximate extension of deciduous oak woodlands (based on CORINE Land Cover 2010) on Lesvos island (Greece) 


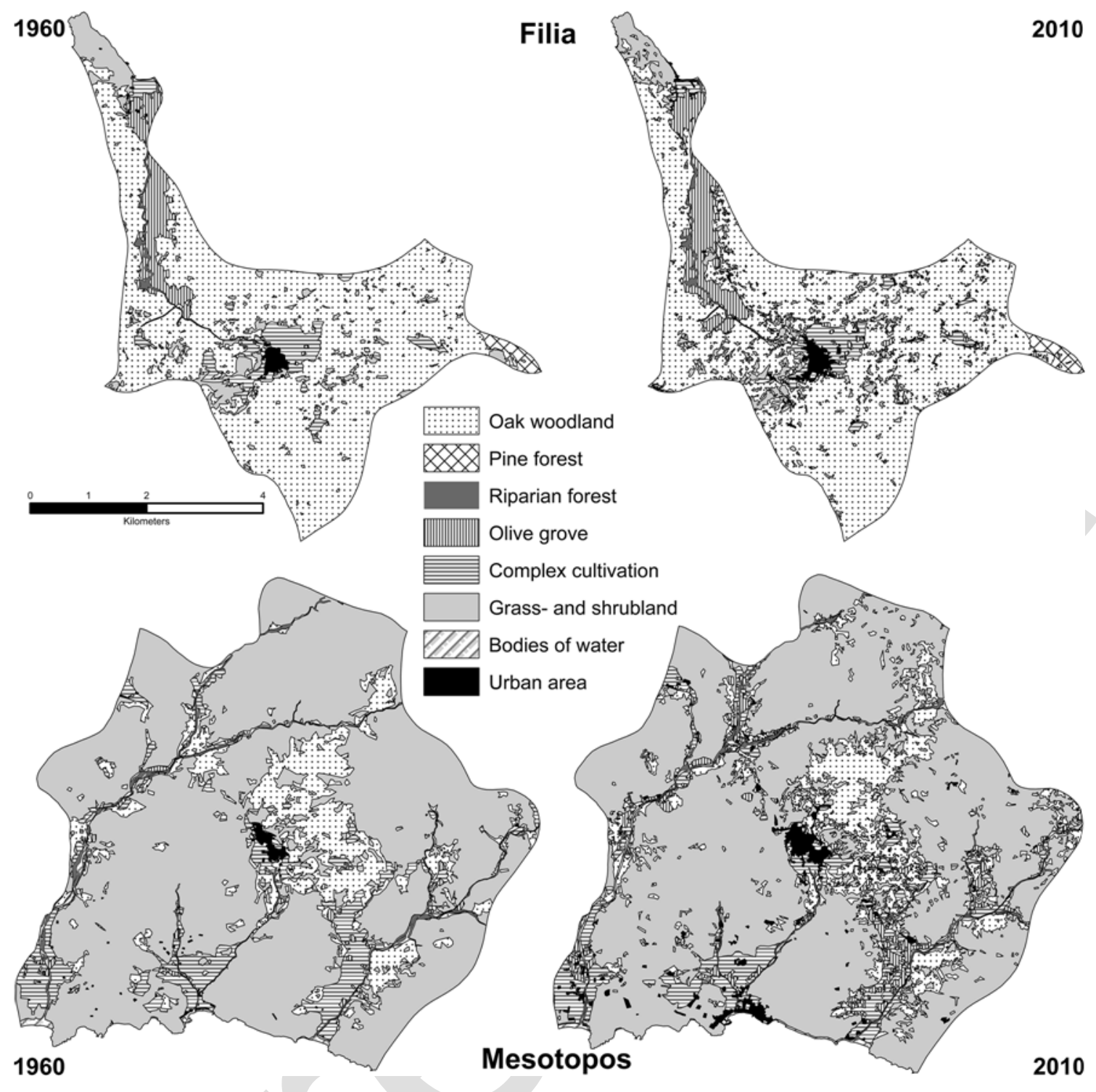

Fig. 2 Land cover dynamics in Filia and Mesotopos between 1960 and 2010 


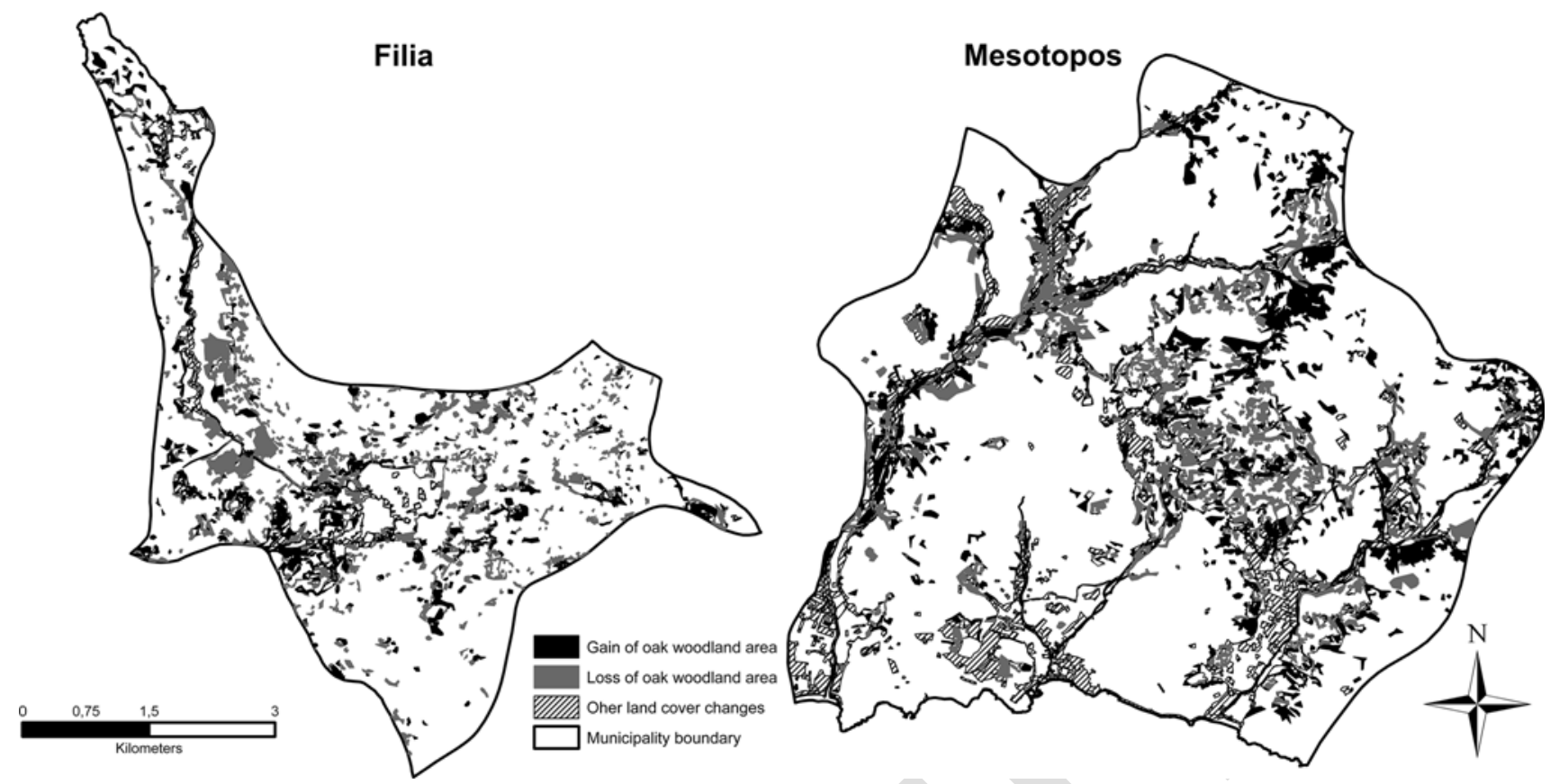

Fig. 3 Oak woodland expansion and loss from 1960 to 2010 in Fila and Mesotopos 

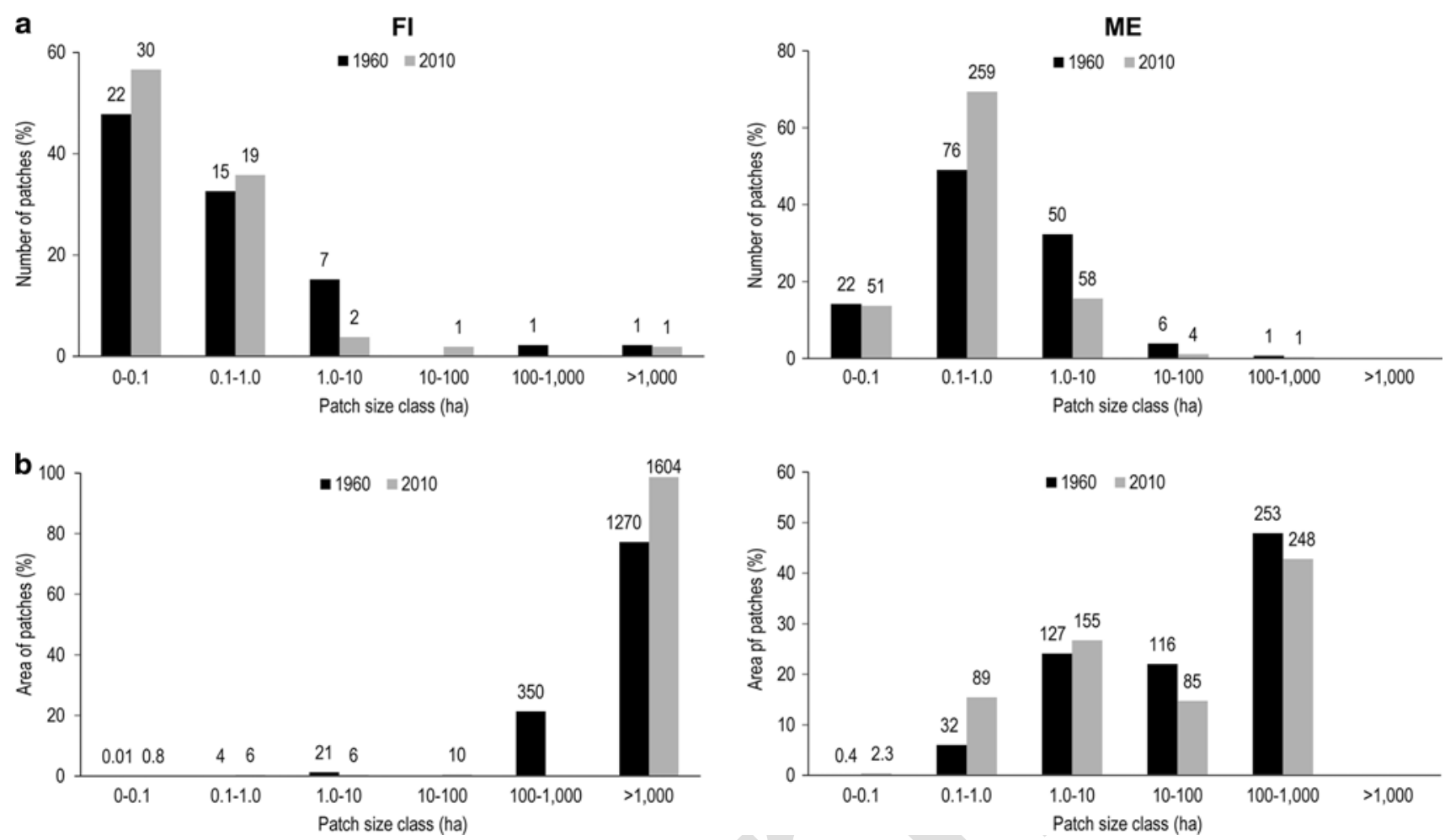

Fig. 4 Percentage of a patches and b total area of oak forest land cover classes in Filia (FI) and Mesotopos (ME) for 1960 and 2010. Absolute a numbers of patches and b areas (ha) are shown above each column 

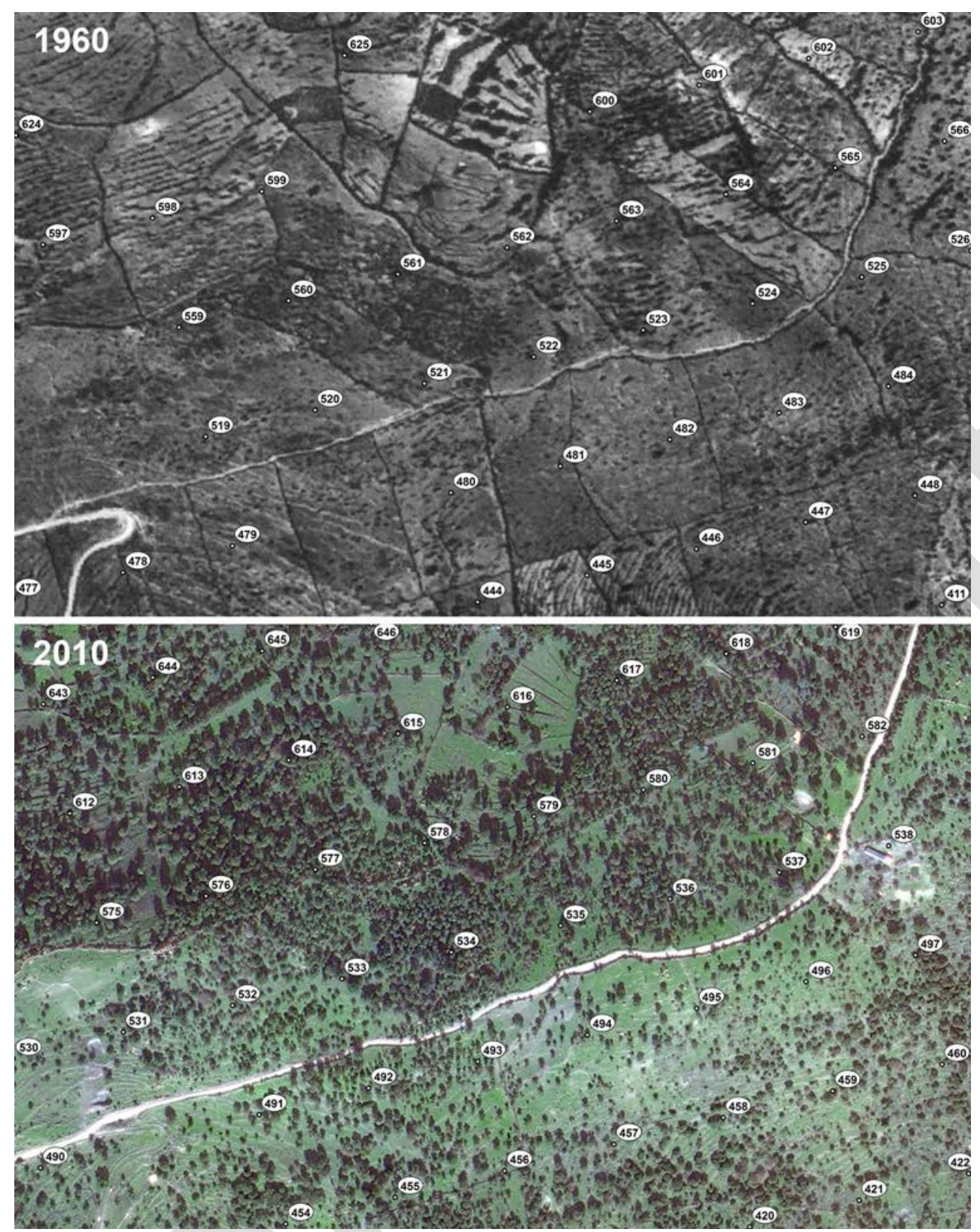

Fig. 5 Dynamics of oak stand density in Filia: Comparison of oak canopy cover between 1960 (above, aerial photograph) and 2010 (below, satellite image) using the grid-point approach 
Table 1. Development of selected socio-economic indicators of the case study municipalities Filia and Mesotopos between 1961 and 2001 (sources: ESYE 1964, 2001)

\begin{tabular}{|c|c|c|c|c|c|c|}
\hline \multirow{2}{*}{ Socio-economic indicator } & \multicolumn{3}{|l|}{ Filia } & \multicolumn{3}{|c|}{ Mesotopos } \\
\hline & 1961 & 2001 & Change (\%) & 1961 & 2001 & Change (\%) \\
\hline Population & 1489 & 690 & -53.7 & 1553 & 981 & -36.8 \\
\hline Number of farms & 404 & 192 & -52.5 & 364 & 203 & -44.2 \\
\hline $\begin{array}{l}\text { Utilized agricultural area } \\
\text { (ha) }\end{array}$ & 1968 & 2129 & 8.2 & 2902 & 2452 & -15.5 \\
\hline Arable land (\% UAA) & 28.1 & 0.2 & -99.3 & 10.6 & 3.9 & -68.8 \\
\hline Grazing land (\% UAA) & 54.9 & 73.2 & 44.3 & 88.2 & 94.0 & 10.0 \\
\hline Number of sheep & 3971 & 8064 & 103.1 & 5532 & 9168 & 65.7 \\
\hline Sheep per farm & 22.4 & 79.8 & 256.3 & 197.6 & 54.6 & -72.3 \\
\hline
\end{tabular}


Table 2. Extent of land cover classes for Filia and Mesotopos in 1960 and 2010 as well as net land cover change as a percentage

\begin{tabular}{|c|c|c|c|c|}
\hline $\begin{array}{l}\text { Land } \\
\text { classes }\end{array}$ & $\begin{array}{l}1960 \text { Area in ha } \\
\text { (\% of total area) }\end{array}$ & $\begin{array}{l}2010 \text { Area in ha } \\
\text { (\% of total area) }\end{array}$ & $\begin{array}{l}\text { Net change of initial } \\
\text { area in ha }(\%)\end{array}$ & $\begin{array}{l}\text { Net change of } \\
\text { total area in \% }\end{array}$ \\
\hline \multicolumn{5}{|l|}{ Filia } \\
\hline Oak woodland & $1670.9(76.8)$ & 1626.5 (74.8) & $-44.4(-2.7)$ & -2.0 \\
\hline Riparian forest & $15.0(0.7)$ & $16.3(0.8)$ & $1.6(10.7)$ & 0.1 \\
\hline Pine forest & $25.8(1.2)$ & $26.2(1.2)$ & $1.3(1.6)$ & $<0.1$ \\
\hline Olive groves & 129.1 (5.9) & $165.5(7.6)$ & 36.4 (28.2) & 1.7 \\
\hline $\begin{array}{ll}\text { Grass- } & \text { and } \\
\text { shrub-land } & \end{array}$ & $176.4(8.1)$ & $214.0(9.8)$ & 37.6 (21.3) & 1.7 \\
\hline $\begin{array}{l}\text { Complex } \\
\text { cultivation }\end{array}$ & $140.0(6.4)$ & $92.9(4.3)$ & $-47.1(-33.6)$ & -2.1 \\
\hline Urban areas & $16.9(0.8)$ & 33.1 (1.5) & $16.2(96.0)$ & 0.7 \\
\hline Water areas & $1.6(0.1)$ & $1.5(0.1)$ & $-0.1(-4.4)$ & 0.0 \\
\hline \multicolumn{5}{|l|}{ Mesotopos } \\
\hline Oak woodland & $527.6(13.7)$ & $580.3(15.1)$ & $52.7(10.0)$ & 1.4 \\
\hline Riparian forest & $33.8(0.9)$ & $27.2(0.7)$ & $-6.5(-19.3)$ & -0.2 \\
\hline Pine forest & - & - & - & - \\
\hline Olive groves & $29.5(0.8)$ & $102.9(2.7)$ & $73.4(249.2)$ & 1.9 \\
\hline $\begin{array}{ll}\text { Grass- } & \text { and } \\
\text { shrub-land } & \end{array}$ & 2903.5 (75.3) & 2764.5 (71.7) & $-139.0(-4.8)$ & -3.6 \\
\hline $\begin{array}{l}\text { Complex } \\
\text { cultivation }\end{array}$ & $300.9(7.8)$ & 282.7 (7.3) & $-18.2(-6.1)$ & -0.5 \\
\hline Urban areas & $16.4(0.4)$ & $64.3(1.7)$ & $47.8(291.0)$ & 1.3 \\
\hline Water areas & $43.2(1.1)$ & $33.0(0.9)$ & $-10.3(-23.7)$ & -0.2 \\
\hline
\end{tabular}


Table 3. Transitions between land cover classes in Filia and Mesotopos between 1960 and 2010

\begin{tabular}{|c|c|c|c|c|c|c|c|c|}
\hline \multirow[t]{2}{*}{1960} & \multicolumn{8}{|l|}{2010} \\
\hline & $\begin{array}{l}\text { Oak } \\
\text { woodland }\end{array}$ & $\begin{array}{l}\text { Riparian } \\
\text { forest }\end{array}$ & $\begin{array}{l}\text { Pine } \\
\text { forest }\end{array}$ & $\begin{array}{l}\text { Olive } \\
\text { groves }\end{array}$ & $\begin{array}{l}\text { Grass- and } \\
\text { shrub-land }\end{array}$ & $\begin{array}{l}\text { Complex } \\
\text { cultivation }\end{array}$ & $\begin{array}{l}\text { Urba } \\
\mathbf{n} \\
\text { areas }\end{array}$ & $\begin{array}{l}\text { Water } \\
\text { areas }\end{array}$ \\
\hline \multicolumn{9}{|l|}{ Filia } \\
\hline $\begin{array}{l}\text { Oak } \\
\text { woodlan } \\
\text { d }\end{array}$ & 69.3 & 0.1 & 0.1 & 2.1 & 5.1 & 0.6 & 0.2 & $<0.01$ \\
\hline $\begin{array}{l}\text { Riparian } \\
\text { forest }\end{array}$ & 0.3 & 0.2 & - & 0.2 & $<0.01$ & $<0.01$ & - & $<0.01$ \\
\hline $\begin{array}{l}\text { Pine } \\
\text { forest }\end{array}$ & 0.1 & - & 1.1 & - & 0.01 & - & - & - \\
\hline $\begin{array}{l}\text { Olive } \\
\text { groves }\end{array}$ & 0.5 & 0.5 & - & 5.0 & 0.02 & $<0.01$ & 0.01 & - \\
\hline $\begin{array}{l}\text { Grass- } \\
\text { and } \\
\text { shrub- } \\
\text { land }\end{array}$ & 3.6 & $<0.01$ & 0.03 & 0.04 & 4.2 & 0.01 & 0.2 & 0.01 \\
\hline $\begin{array}{l}\text { Comple } \\
\mathrm{x} \\
\text { cultivati } \\
\text { on }\end{array}$ & 1.6 & $<0.01$ & - & 0.3 & 0.6 & 3.6 & 0.4 & $<0.01$ \\
\hline $\begin{array}{l}\text { Urban } \\
\text { areas }\end{array}$ & 0.02 & - & - & 0.02 & $<0.01$ & $<0.01$ & 0.7 & - \\
\hline $\begin{array}{l}\text { Water } \\
\text { areas }\end{array}$ & 0.02 & 0.01 & - & $<0.01$ & $<0.01$ & $<0.01$ & $<0.01$ & 0.03 \\
\hline \multicolumn{9}{|c|}{ Mesotopos } \\
\hline $\begin{array}{l}\text { Oak } \\
\text { woodlan } \\
\text { d }\end{array}$ & 7.4 & 0.02 & - & 0.4 & 4.7 & 0.8 & 0.2 & 0.06 \\
\hline $\begin{array}{l}\text { Riparian } \\
\text { forest }\end{array}$ & 0.2 & 0.1 & - & 0.05 & 0.2 & 0.2 & $<0.01$ & 0.1 \\
\hline
\end{tabular}




\begin{tabular}{|c|c|c|c|c|c|c|c|c|}
\hline \multirow[t]{2}{*}{1960} & \multicolumn{8}{|l|}{2010} \\
\hline & $\begin{array}{l}\text { Oak } \\
\text { woodland }\end{array}$ & $\begin{array}{l}\text { Riparian } \\
\text { forest }\end{array}$ & $\begin{array}{l}\text { Pine } \\
\text { forest }\end{array}$ & $\begin{array}{l}\text { Olive } \\
\text { groves }\end{array}$ & $\begin{array}{l}\text { Grass- and } \\
\text { shrub-land }\end{array}$ & $\begin{array}{l}\text { Complex } \\
\text { cultivation }\end{array}$ & $\begin{array}{l}\text { Urba } \\
\mathbf{n} \\
\text { areas }\end{array}$ & $\begin{array}{l}\text { Water } \\
\text { areas }\end{array}$ \\
\hline $\begin{array}{l}\text { Pine } \\
\text { forest }\end{array}$ & - & - & - & - & - & - & - & - \\
\hline $\begin{array}{l}\text { Olive } \\
\text { groves }\end{array}$ & 0.1 & $<0.01$ & - & 0.4 & 0.08 & 0.2 & $<0.01$ & 0.02 \\
\hline $\begin{array}{l}\text { Grass- } \\
\text { and } \\
\text { shrub- } \\
\text { land }\end{array}$ & 6.5 & 0.02 & - & 0.6 & 65.5 & 1.6 & 0.7 & 0.2 \\
\hline $\begin{array}{l}\text { Comple } \\
\text { x } \\
\text { cultivati } \\
\text { on }\end{array}$ & 0.6 & 0.09 & - & 1.2 & 1.1 & 4.3 & 0.4 & 0.07 \\
\hline $\begin{array}{l}\text { Urban } \\
\text { areas }\end{array}$ & $<0.01$ & $<0.01$ & - & $<0.01$ & 0.03 & 0.05 & 0.3 & $<0.01$ \\
\hline $\begin{array}{l}\text { Water } \\
\text { areas }\end{array}$ & 0.2 & 0.08 & - & 0.04 & 0.2 & 0.2 & 0.04 & 0.4 \\
\hline
\end{tabular}


Table 4. Landscape structure changes in Filia and Mesotopos based on Land cover metrics at land cover class-level of six land cover types present in both municipalities

\begin{tabular}{|c|c|c|c|c|c|c|c|c|}
\hline \multirow[t]{2}{*}{ Class-level metrics } & \multicolumn{2}{|l|}{ NP } & \multicolumn{2}{|c|}{ MPS (ha) } & \multicolumn{2}{|c|}{ ED $\left(m h^{-1}\right)$} & \multicolumn{2}{|c|}{ LPI (\%) } \\
\hline & 1960 & 2010 & 1960 & 2010 & 1960 & 2010 & 1960 & 2010 \\
\hline \multicolumn{9}{|l|}{ Filia } \\
\hline Oak woodland & 46 & 53 & 36.3 & 30.7 & 21.2 & 38.1 & 21.5 & 26.6 \\
\hline Riparian forest & 18 & 7 & 0.8 & 2.3 & 2.5 & 2.7 & 0.2 & 0.3 \\
\hline Olive groves & 10 & 31 & 12.9 & 5.3 & 3.5 & 5.6 & 1.5 & 1.5 \\
\hline Grass- and shrub-land & 221 & 520 & 0.8 & 0.4 & 14.8 & 32.8 & 1.1 & 0.9 \\
\hline Complex cultivation & 45 & 26 & 3.1 & 5.3 & 6.6 & 5.2 & 0.9 & 0.8 \\
\hline Urban areas & 26 & 31 & 0.7 & 1.1 & 1.2 & 3.7 & 0.2 & 0.4 \\
\hline \multicolumn{9}{|l|}{ Mesotopos } \\
\hline Oak woodland & 155 & 373 & 3.4 & 1.6 & 32.6 & 62.9 & 4.2 & 4.1 \\
\hline Riparian forest & 123 & 60 & 0.3 & 0.5 & 8.8 & 7.1 & 0.1 & 0.1 \\
\hline Olive groves & 67 & 123 & 0.4 & 0.8 & 4.0 & 10.9 & $<0.1$ & 0.3 \\
\hline Grass- and shrub-land & 106 & 230 & 27.4 & 12.0 & 38.1 & 65.5 & 24.6 & 15.6 \\
\hline Complex cultivation & 93 & 115 & 3.2 & 2.6 & 16.3 & 19.6 & 1.2 & 0.6 \\
\hline Urban areas & 53 & 79 & 0.3 & 0.8 & 2.2 & 7.7 & 0.2 & 0.4 \\
\hline
\end{tabular}

$N P$ number of patches, MPS mean patch size, ED edge density, $L P I$ largest patch index 
Table 5. Absolute (km) and relative (\%) adjacency between oak woodland and the other land cover classes in Filia and Mesotopos for 1960 and 2010

\begin{tabular}{|c|c|c|c|c|c|c|}
\hline \multirow[t]{3}{*}{ Adjacenct class } & \multicolumn{4}{|c|}{ Adjacency index } & \multicolumn{2}{|c|}{ Change 1960-2010 } \\
\hline & \multicolumn{2}{|l|}{1960} & \multicolumn{2}{|l|}{2010} & \multirow[t]{2}{*}{ Absolute } & \multirow[t]{2}{*}{ Relative } \\
\hline & km & $\%$ & km & $\%$ & & \\
\hline \multicolumn{7}{|l|}{ Filia } \\
\hline Riparian forest & 5.6 & 5.4 & 4.8 & 2.6 & -0.8 & -14.3 \\
\hline Pine forest & 1.6 & 1.5 & 1.4 & 0.8 & -0.2 & -12.5 \\
\hline Olive groves & 8.0 & 7.8 & 12.6 & 6.9 & +4.6 & +57.6 \\
\hline Grass- and shrub-land & 64.7 & 62.8 & 149.9 & 81.6 & +85.2 & +131.7 \\
\hline Complex cultivation & 20.3 & 19.7 & 9.5 & 5.2 & -10.8 & -53.2 \\
\hline Urban areas & 1.2 & 1.2 & 4.9 & 2.7 & +3.7 & +308.3 \\
\hline Water areas & 1.6 & 1.6 & 0.6 & 0.2 & -1.0 & -62.5 \\
\hline Total & 103.0 & 100.0 & 183.7 & 100.0 & +80.7 & +78.4 \\
\hline \multicolumn{7}{|l|}{ Mesotopos } \\
\hline Riparian forest & 9.4 & 6.0 & 9.7 & 3.2 & +0.3 & +3.2 \\
\hline Olive groves & 2.4 & 1.5 & 9.7 & 3.2 & +7.3 & +304.2 \\
\hline Grass- and shrub-land & 120.0 & 76.7 & 253.3 & 84.1 & +133.3 & +111.1 \\
\hline Complex cultivation & 18.4 & 11.7 & 15.1 & 5.0 & -3.3 & -17.9 \\
\hline Urban areas & 1.2 & 0.8 & 4.1 & 1.4 & +2.9 & +241.7 \\
\hline Water areas & 5.0 & 3.3 & 9.3 & 3.1 & +4.3 & +86.0 \\
\hline Total & 156.4 & 100.0 & 301.2 & 100.0 & +144.8 & +92.6 \\
\hline
\end{tabular}

